\title{
University Libraries as Advocates for Latin American Indigenous Languages and Cultures
}

\author{
Kathia S. Ibacache
}

\begin{abstract}
The revitalization of Latin American Indigenous languages started many years ago, but only some university libraries in the United States have taken steps to advocate for preservation, access, inclusion, and diversity through collection building covering these languages and cultures. This study examines holdings of Quechua, Nahuatl, Guaraní, Zapotec, Maya, Mapudungun, and Aymara materials in 87 university libraries in the United States. This study seeks to answer the question: are university libraries in the United States supporting inclusion and diversity through the purchase of Latin American Indigenous language materials? In addition, the author explores what initiatives university libraries could take to further the revitalization and advancement of these Indigenous languages.
\end{abstract}

\section{Introduction}

The revitalization and preservation of Latin American Indigenous languages, cultures, and knowledge is an ongoing endeavor for some universities in the United States, often empowered by initiatives of inclusion and diversity. The expansion of these initiatives to a broader number of universities may support the preservation of the cultures and languages of Latin American Indigenous peoples. University libraries, as a nuclear component of a university, could play a significant role in advancing the inclusion of Latin American Indigenous languages into library services, through the creation of collections, promotion of collections, and being part of a network of on-campus collaboration that educates and fosters understanding of the importance of protecting Indigenous knowledge and the historical past that Indigenous cultures represent.

This study seeks to answer the following question: are university libraries in the United States supporting inclusion and diversity through the purchase of Latin American Indigenous language materials? In addition, the author explores what initiatives university libraries could take to further the revitalization and advancement of these Indigenous languages.

First, this study provides background information on the revitalization of Latin American Indigenous languages, Indigenous knowledge, and Indigenous authors. The study also researched the courses or programs covering the languages and cultures of seven Latin American Indigenous languages (Quechua, Nahuatl, Guaraní, Zapotec, Maya, Mapudungun, and Aymara) offered in 87 universities in the United States. ${ }^{1}$ These are the most widely spoken Indigenous languages in Latin America. ${ }^{2}$ Quechua is spoken in Perú, Bolivia, Ecuador, Colombia, and Argentina; ${ }^{3}$ Mayan

Kathia Ibacache is Romance Languages Librarian and Assistant Professor at the University of Colorado Boulder, email: kathia.ibacache@colorado.edu. (C) 2021 Kathia Ibacache, Attribution-NonCommercial (https://creativecommons.org/licenses/by-nc/4.0/) CC BY-NC. 
languages are spoken in Guatemala, Belize, and Southern Mexico; ${ }^{4}$ Guaraní is spoken in Paraguay, Argentina, and Brazil.; Aymara languages are spoken in Perú and Bolivia; ${ }^{6}$ Zapotec and Nahuatl languages are spoken in Mexico; ${ }^{7}$ and Mapudungun is spoken in Chile and Argentina. ${ }^{8}$ Second, this study offers data on the amount of materials in these languages held by the 87 university libraries. Third, the author provides recommendations for university libraries to advance the preservation and promotion of Latin American Indigenous languages, thereby enhancing students' opportunities to become global learners and increasing awareness of other cultures.

This study was inspired by a graduate student who alerted the author to the lack of materials in Latin American Indigenous languages and cultures at the University of Colorado Boulder (UCB). This conversation prompted an inquiry to know whether other university libraries from research universities were purchasing materials related to Latin American Indigenous languages and cultures. The author found this subject interesting because of its connection to a Latin American subject associated with inclusion and diversity, which UCB's University Library upholds through its Diversity Statement. ${ }^{9}$ The author also wanted to learn about the current state of the collections in academic libraries, which are members of the Association of Research Libraries (ARL).

\section{Background}

Scholarship relating to Latin American Indigenous languages in university libraries' collections in the U.S. is sparse. However, diversity and inclusion are increasingly relevant for academic libraries, possibly to secure a just and balanced student and employee recruitment system, to attract talented students and employees, and to provide equal opportunities and an educational experience that is rich with diverse backgrounds. The American Council of Education, referring to the importance of diversity in higher education, notes that "we learn from those whose experiences, beliefs, and perspectives are different from our own, and these lessons can be taught best in a richly diverse intellectual and social environment."10 Similarly, diversity and inclusion are key points in the American Library Association Strategic Directions, especially as stated in the Goals for "Equity, Diversity, and Inclusion." 11 One goal is pertinent in this research. This goal "establishes ALA as a major voice for the values of equity, diversity, and inclusion in all areas of information policy."12

University libraries may strive toward reaching this goal by empowering academic librarians to "advocate within their own workplace."13 When it comes to Latin American Indigenous languages, librarians may play a crucial role in the selection and collection of materials, the facilitation of access and discoverability, and the promotion and preservation of Indigenous knowledge. For background purposes, the following offers some information on the revitalization of Latin American Indigenous languages, the emergence of Indigenous authors, and the libraries' role in advancing inclusion and diversity through the promotion, collection development, preservation, and access to Latin American Indigenous languages materials and preservation of Indigenous knowledge.

\section{Revitalization: Literature Impact, Marginalization, and Education to Preserve Indigenous Knowledge}

The revitalization of some Latin American Indigenous languages such as Quechua started many years ago with the advancement of rural education and later the integration of Indigenous peoples in urban mestizo communities in Peru. ${ }^{14}$ In other words, Indigenous peoples 
began moving into the cities, where women and men of mixed race (usually Spanish and Indigenous descent) live. While knowing Quechua in the city was cause for marginalization, once these Indigenous peoples had access to education, even if it was an education taught in the Spanish language, a number of Indigenous authors appeared, expressing Indigenous subjects and traditions from their own viewpoint. Although Latin American Indigenous authors initially opened a space for themselves writing in Spanish, a shift took place where these writers started producing literary work in their native languages. ${ }^{15}$ For example, expert on Amerindian literature Gonzalo Espino Relucé, addressing the Peruvian political landscape, stated that a Quechua narrative started to rise up against the well-established Peruvian Spanish literature in the 1970s. ${ }^{16}$

The interaction between Spanish and Indigenous languages defines authors such as Porfirio Meneses, who uses Spanish, the "dominant language," to refer to everyday themes lived by the Huanta Quechuas. ${ }^{17}$ Other writers, like Macedonio Villafán, interlace a narrative that exemplifies both the "knowledge of Andean ancestors" and the culture of the "invader" in what is called cross-cultural literature. ${ }^{18}$ Villafán's tales exhibit a "bicultural" nature where the Spanish and Quechua languages symbolize the tensions that arise between modernized Indigenous people, who are influenced by modernity and their desire to keep their Indigenous culture. ${ }^{19}$

Nonetheless, Indigenous peoples have long struggled with marginalization and a misrepresentation of inferiority promulgated by colonizers throughout history until today. Specialist on Indigenous rights advocacy Karine Vanthuyne, writing about the Mayan identity in Guatemala, states that this misconception fueled the economic exploitation and segregation of native peoples. ${ }^{20}$ The incorporation of an Indigenous language into an education system constitutes one path to reduce marginalization and provide inclusion by governments that seek to advocate for native peoples.

Sociology Professor and researcher on Indigenous studies Vivian Jiménez Estrada refers to the work of Indigenous scholars to transmit the value of traditional knowledge found in Indigenous cultures such as the Mayan culture. ${ }^{21}$ In particular, Jiménez sees the poetry of Maya Cú as a means to validate Mayan cultural identity in Guatemala and to assert that Mayan Indigenous knowledge is not a practice of the past, but a practice that invigorates as it is transferred from generation to generation. ${ }^{22}$ For Jiménez, Cú's work retells historical events highlighting Mayan values, especially relating to the significance of Mayan women, which is in opposition to the narrative of colonial history. ${ }^{23}$ Diversity and inclusion may also arise by conserving Indigenous knowledge. Here university libraries and universities may play an important role.

\section{Libraries' Role}

Although some universities have taken a lead in the advancement of Indigenous language and cultures through programs and courses, diversity and inclusion in academic library collections for the most spoken Latin American Indigenous languages still represents an area in need of growth. University libraries are in a distinct position to promote diversity and inclusion by collaborating with departments that might initiate programs, by fostering the creation of Indigenous collections, and by promoting these collections both in class and on campus to secure impact and make sure students know about these materials.

At least one organization is relevant for librarians who are interested in creating and promoting a collection that involves Latin American Indigenous languages. The Seminar on 
the Acquisition of Latin American Library Materials (SALALM), an organization for academic librarians, archivists, book vendors, researchers, and students, advocates for access to resources in all formats and the development of library collections in "support of educational research." SALALM also advocates for the dissemination of "bibliographic information" of publications regarding Latin America. ${ }^{24}$ In addition, SALALM also offers a subcommittee on marginalized peoples and ideas, which seeks to improve collections produced by marginalized peoples and promote "a better awareness of the nature of these materials, their significance, and how to go about obtaining them." 25

\section{Collection Development}

Librarian and researcher on Native studies David L. Alexander, noting the work of libraries in supporting American Indian studies programs, argues that collection development should consider nontraditional publishers that provide Indigenous materials. ${ }^{26}$ Similarly, Américo Mendoza-Mori implies that addressing an Indigenous culture builds "awareness of cultural diversity" in students. ${ }^{27}$ Addressing assessments for diversity in academic library collections, Librarians Matthew P. Ciszek and Courtney L. Young recommend the creation of a policy or "statement" that distinctly states the need to acquire materials that represent diversity. ${ }^{28}$ A policy or statement is critical because it documents a collection development change that should be followed by librarians in charge of collections. This statement also sets a tone signaling the objective that university libraries are undertaking to support diversity and inclusion.

Even though policies are helpful, there is a need for materials. Some authors refer to this challenge acknowledging that there is a lack of materials written by Indigenous authors and materials written for an Indigenous audience. ${ }^{29}$ Argentinian librarian Daniel Canosa adds that even libraries located within Indigenous communities do not have collections that reflect the local knowledge of the people they are trying to include. ${ }^{30}$ Barbara I. Dewey, referring to the Association of Research Libraries' initiatives to advance diversity, affirms that welcoming different people and diverse ideas serves to further the "human experience." 31

Canosa emphasizes that building collections based on books written in Spanish about Indigenous peoples, or even having bilingual dictionaries and other materials that refer to Indigenous peoples in Latin America, is not enough to constitute a collection that is Indigenous in nature. ${ }^{32}$ Canosa surmises that an Indigenous collection should hold materials that represent the cultural and communal knowledge of Indigenous peoples. This knowledge encompasses the preservation of a historic truth, or "verdad histórica," that includes oral tradition, murals, sculptures, and manuscripts, and other forms of expression, which need to be kept alive. ${ }^{33}$ Florence Dedzoe-Dzokoto Plockey, referring to African Indigenous knowledge, expresses that Indigenous knowledge, seen as inferior and hostile to development by colonizers, placed Indigenous peoples in an inferior position. ${ }^{34}$ Moreover, acculturation has adversely affected Indigenous knowledge, prompting Indigenous peoples to lose their identity by dismissing the value of Indigenous dressing, worshipping, and traditional celebrations, among other identifying features. ${ }^{35}$

University libraries are consequential characters in the access and preservation of knowledge. Dedzoe-Dzokoto realized, through interviews with academic librarians from four state universities in Ghana, that these academic libraries were not concerned with advancing and protecting oral traditions. ${ }^{36}$ In a different continent, researcher on Indigenous knowledge and libraries Martin Nakata, addressing Australian libraries' commitment to advocate for Indig- 
enous peoples' interests through archives, conferences, and publications, conveyed that, while Indigenous collections are relevant to a nation's heritage, these collections should be readily available to Indigenous peoples. ${ }^{37}$

\section{Outreach Efforts: Making Materials Accessible}

Diversity and inclusion could also be fostered through a collaboration among Indigenous peoples, Indigenous libraries, and university libraries. A librarian who specializes in library services for Indigenous peoples, Edgardo Civallero, notes that libraries could support the "cultural recovery" of Indigenous peoples by enabling positive interactions between the Indigenous peoples and those representing the dominant society.$^{38}$ For example, Civallero refers to the implementation of a bookmobile by the Frontera University in Temuco, Chile, which collected the sounds of the Mapudungun language..$^{39}$

Other entities that may advance inclusion and diversity are Latin American publishers and book vendors, who play a pivotal role in the dissemination of Indigenous knowledge by providing access to fiction and informational books, including literary criticism on matters of Latin American Indigenous languages and cultures, especially if these books are written by Indigenous authors. Kathia Ibacache, writing about the representation of books published in Hispano-American countries in university libraries in the United States, refers to books with literary value, including those related to Latin American Indigenous languages that could be found in Latin American publishing houses. ${ }^{40}$

Developing a collection of materials in Latin American Indigenous languages stimulates diversity and inclusion, especially if this collection considers materials written or produced by Indigenous authors. If one considers Indigenous peoples as part of minority groups, then purchasing and developing a collection that represents these Indigenous peoples supports diversity. Advocating for the dissemination of knowledge about Latin American Indigenous languages and cultures through an inclusive collection may enable an interaction among students, professors, and these languages and cultures that may benefit all the participants in this equation. Thus, Indigenous knowledge derived from these materials may not only assert the value of preserving Indigenous knowledge and historical truth; it may also build a bridge that connects Indigenous peoples to university students.

\section{Methodology}

This study answers the following question: Are university libraries in the United States supporting inclusion and diversity through the purchase of Latin American Indigenous language materials? To establish whether university libraries were acquiring items in any of the languages covered in this paper, the author quantified the number of items found in the collections of 87 US universities. Similarly, the author wanted to know the incidence of courses or programs in the languages covered that had been offered in these universities.

This study defines "materials" as those included in the Online Computer Library Center's (OCLC) filters in FirstSearch's expert search. These materials are: books, internet resources, computer files, visuals, musical scores, archival materials, sound recordings, serial publications, and maps. OCLC is a cooperative library that offers access to bibliographic data from libraries around the world. ${ }^{41}$ These 87 universities were chosen because they are members of both ARL and OCLC. ${ }^{42}$ The author chose to focus on ARL libraries because their members are considered research libraries. The languages are: Aymara, Guaraní, Mayan languages, 
Mapudungun, Nahuatl, Quechua, and Zapotec. As stated above, these languages were chosen as they represent the most spoken Indigenous languages in Latin America.

The first step was identifying a discovery platform that allowed a search of materials in these languages. This step was challenging due to the lack of uniform language filters among universities' online catalogs. For example, the University of California, Berkeley's online catalog OskiCat contains only 16 languages in its Advance Search language feature, none of which is one of the languages covered in this study. Similarly, the University of Texas at Austin's Advance Search's language filter contains 88 languages with only two matches for the languages in this study, although it does have a language filter for "South American Indian." The searches were not limited by the year of publication, to allow the system to retrieve all materials available in these seven Indigenous languages.

Ultimately, OCLC's FirstSearch expert search feature was chosen because it allowed a search in each one of the languages relevant to this study. The searches included a search term such as Quechua, indexed in: language phrase $(\ln =)$, with no limits on year of publication and number of libraries. The searches were opened to all types of materials and limited by "any audience," "any content," and "any format." Each search contained the library code of the corresponding 87 university libraries contemplated in this study. The author also consulted with an OCLC customer support librarian who provided input on the most appropriate search processes to look for all holdings by specific academic libraries in the languages covered in this paper.

\section{OCLC Limitations}

Using OCLC FirstSearch posed three limitations that are important to consider:

1. The number of holdings retrieved by OCLC FirstSearch's searching engine was affected by the metadata entered by librarians in their home libraries. If this metadata did not include one of the languages contemplated in this study, even when the language was present in the material, then this record would not appear in the results.

2. The number of holdings retrieved was affected by university libraries' practices as to uploading of records, and backlogs, if any. Therefore, if a library had not uploaded its records, then OCLC FirstSearch would not be able to retrieve them.

3. Electronic book (e-book) records are usually not uploaded into OCLC. As a result, ebooks written or using the languages in this study would not be retrievable through OCLC FirstSearch either.

\section{Courses and Programs Search}

To quantify the number of courses offered by universities in any of the seven languages covered in this study, the author used internet searches of the 87 university websites included in this study. The searches contemplated the different terms associated with some of these languages. To illustrate, for Mayan languages, the search terms included Maya, K'iche, Quiché, and Yucatec. In the case of Mapudungun, the search also entailed the term "Mapuche." All of the courses and language programs found and considered in the data were taught between 1998 through $2019 .^{43}$

The course listings included in this study refer to topics on language and cultures for any of the seven languages. These courses were provided by various departments including Modern Languages and Classics, Linguistics, Native American Studies, Spanish and Portu- 
guese, Latin American Studies Program Department, and the Center for Latin American and Caribbean Studies. Interestingly, other departments or schools also offered relevant courses. To illustrate, the George Washington University's School of Business offers courses in Quechua and other less commonly taught languages through its Global Language Network, a student organization that seeks to "connect and empower people through language and culture." 44

According to these courses and programs' webpage listings, some offered written and communication skills in the given language and knowledge of the Indigenous culture. Other courses explore the work of writers, who advance Indigenous knowledge. Some of these courses and programs were offered on a regular basis and others were offered occasionally. Similarly, depending on the university, some courses fulfilled language requirements while others did not. These language and culture courses were usually taught at the elementary and intermediate levels. Searches did not include courses related to arts and anthropology.

\section{Findings and Discussion}

The data gathered through OCLC FirstSearch regarding the 87 university libraries' holdings for materials in seven Latin American Indigenous languages were collected in October 2019. The results show that, although all 87 of these university libraries have a representation of materials in at least one of these languages in any of the 10 different types of materials, the amount of representation varies. Figure 1 shows that the majority of these universities have either 50 or fewer items in these Indigenous languages, or approximately 101 to 500 holdings. Only 6 percent of universities have 500 or more holdings.

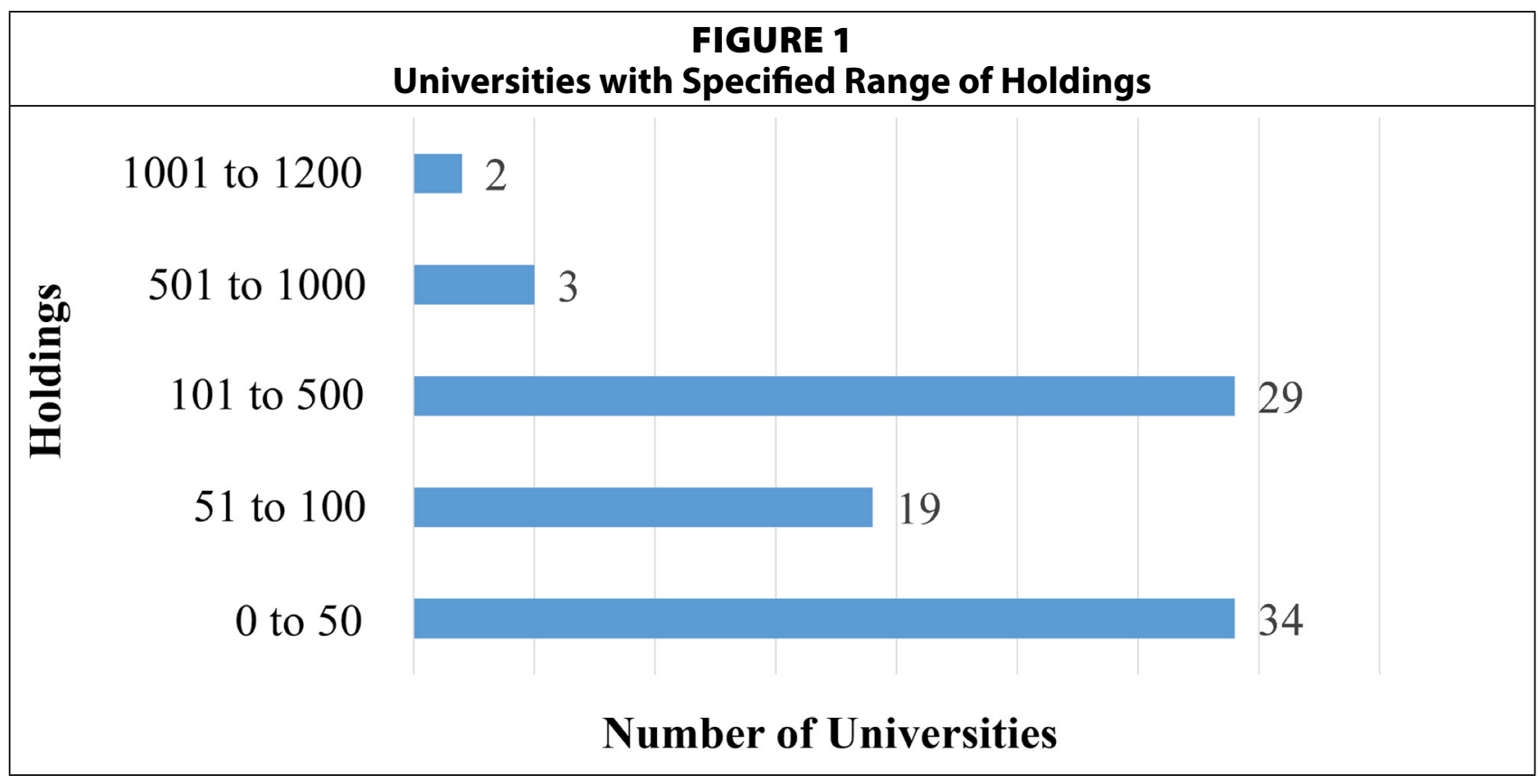

Figures 2 and 3 show the 11 university libraries with the most holdings of materials, and the 11 university libraries with the least holdings in the Indigenous languages covered. This data emphasizes the disparity of holdings among the university libraries. This data also indicates that five university libraries, roughly 6 percent of the 87 universities, have a holding representation in the lower single digits. 


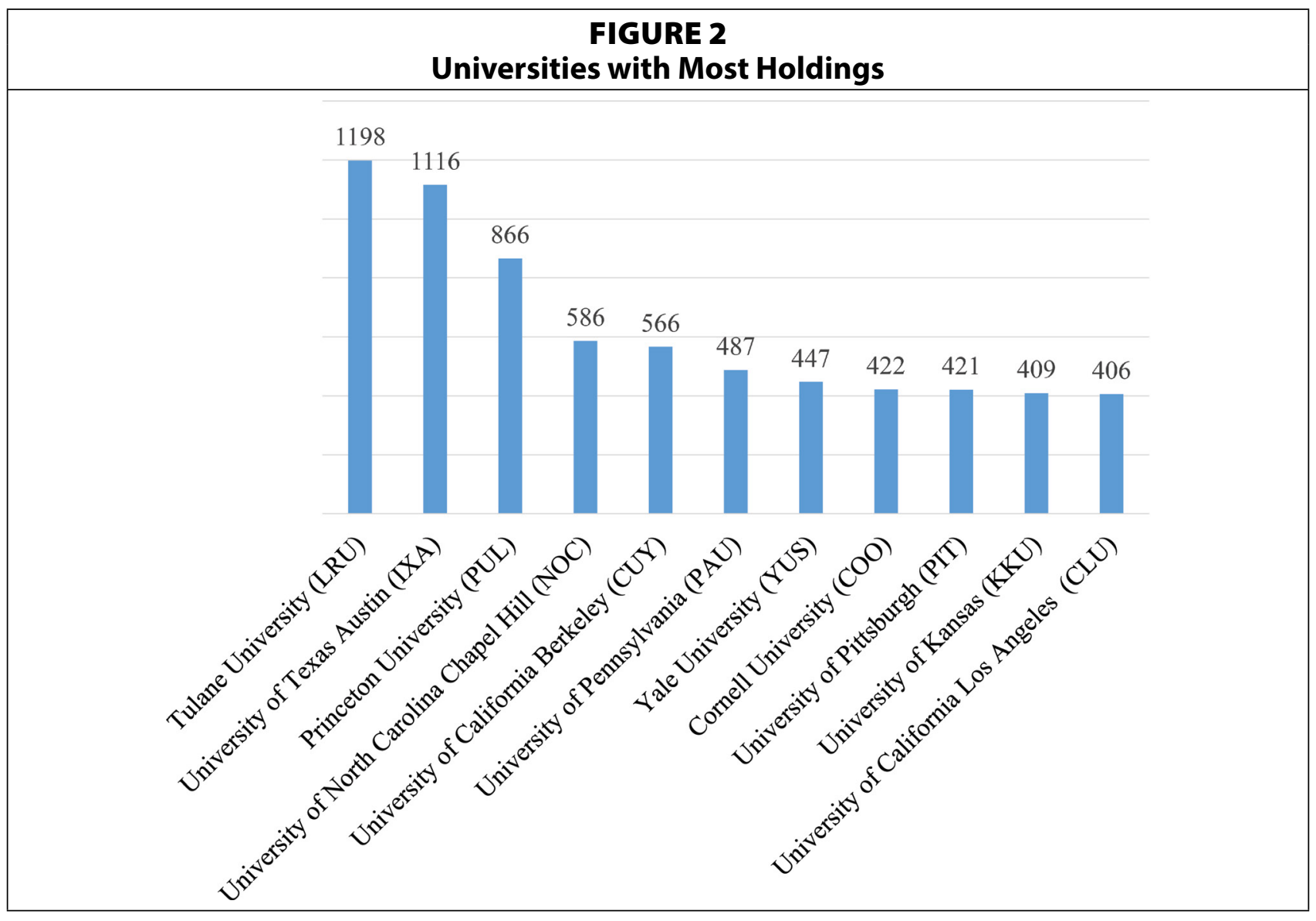

\section{FIGURE 3}

\section{Universities with Least Holdings}
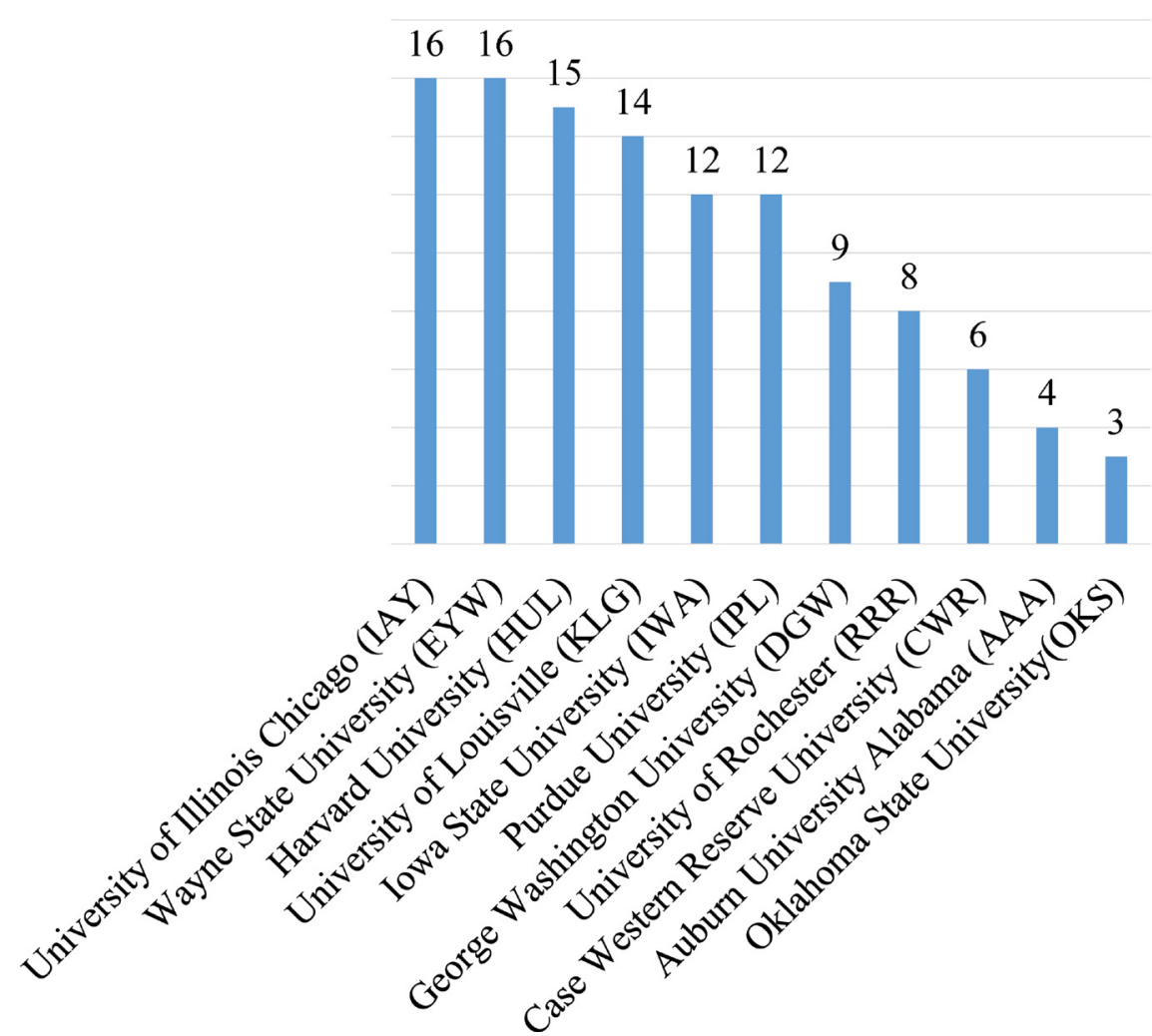
As noted in figure 4, Mayan languages materials $(6,729)$ have the highest number of holdings in all 87 university libraries, followed distantly by Quechua language materials $(3,102)$. Materials in Nahuatl $(1,641)$ and Guaraní $(1,489)$ languages share similar amounts of holdings, while there is a decline in the amount of materials in Aymara (782), Zapotec (560), and Mapudungun (371) languages. Mayan languages have 18 times more material holdings than Mapudungun, the language with the smallest number of holdings. Mayan languages have double the number of holdings than Quechua language materials, even though Quechua is the most widely spoken of these Indigenous languages. ${ }^{45}$ Interestingly, through email correspondence with three Latin American publishing houses (Pakarina Ediciones, Abya Yala Editorial, and F\&G Editores), the author learned that these houses in the aggregate publish approximately 160 titles per year in various Indigenous languages, including Quechua, Aymara, Tsolsil, Mapudungun, Shuar, Sápara, Buglere, and Cakchiquel. ${ }^{46}$

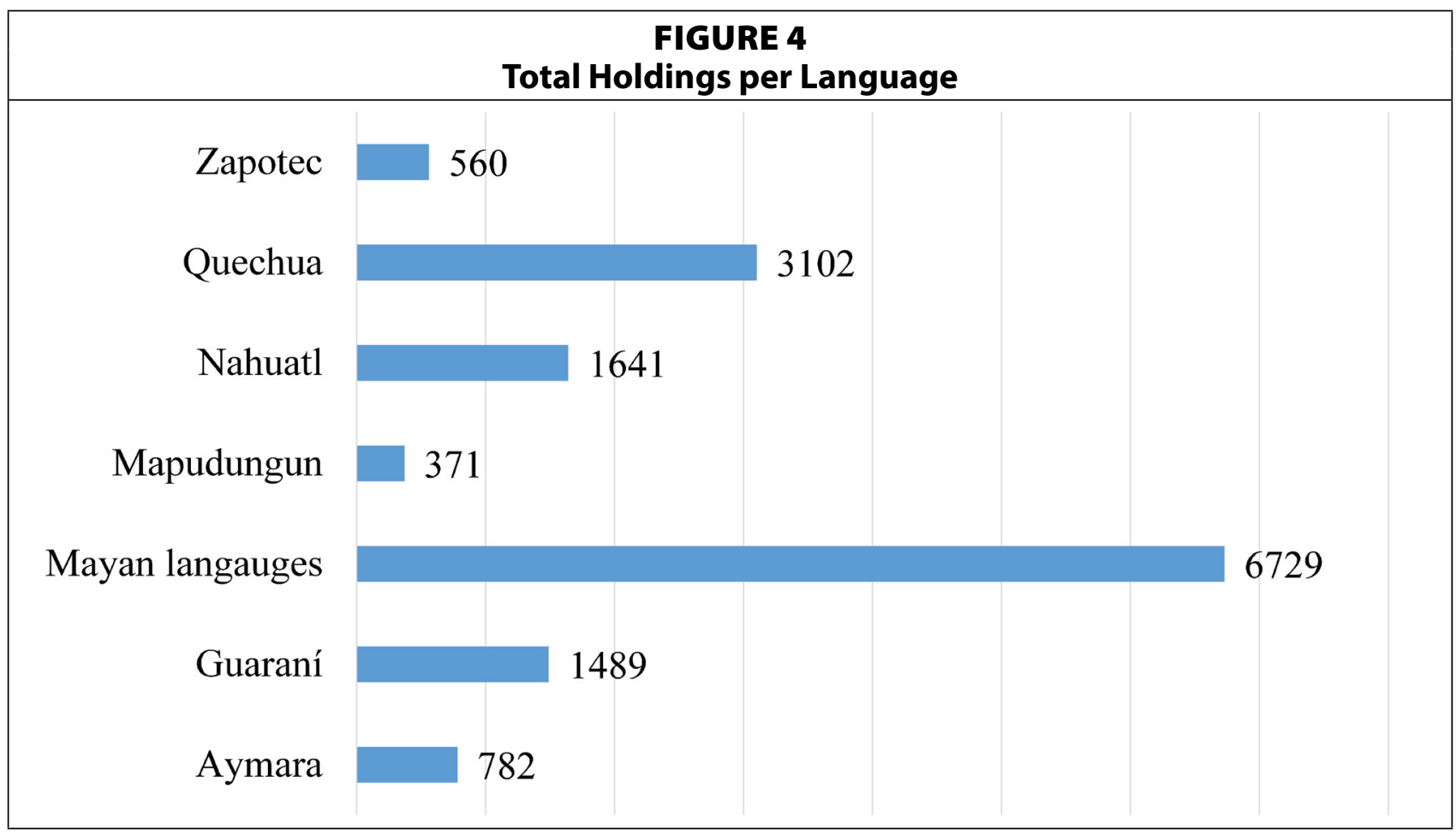

This study considered 10 different types of materials held in the 87 university libraries. Of these types of materials, books, comprising 81.6 percent of the total number of materials, surpasses the number of holdings considerably. Only sound recordings, in any of the seven Indigenous languages searched, at 8 percent of the total holdings, have a slightly larger representation than the rest of the types of materials. Computer and Internet resources have a combined 4.8 percent of holding representation, while visual materials have 3.3 percent of representation. Interestingly, visual materials have a minimal representation even when there is a fair number of films available in Latin American Indigenous languages, or in a bilingual Spanish/Indigenous edition, produced since the early twentieth century. Therefore, the small representation in university libraries may be due to a lack of conscientious effort to acquire these films, as opposed to a lack of filmography. 


\section{Courses and Programs Data}

With regard to courses and programs offered between 1998 to 2019 at the universities identified in the internet search, figure 5 shows that courses or programs on Quechua language and/or culture have the largest representation, at 27 percent of the total. Sixteen percent of universities have offered courses or programs in Nahuatl, 15 percent have offered courses or programs in Mayan languages and/or cultures, and 4.3 percent have offered courses or programs in Zapotec. Courses on Guaraní, Aymara, and Mapudungun language and culture had the smallest representation of courses in the universities considered.

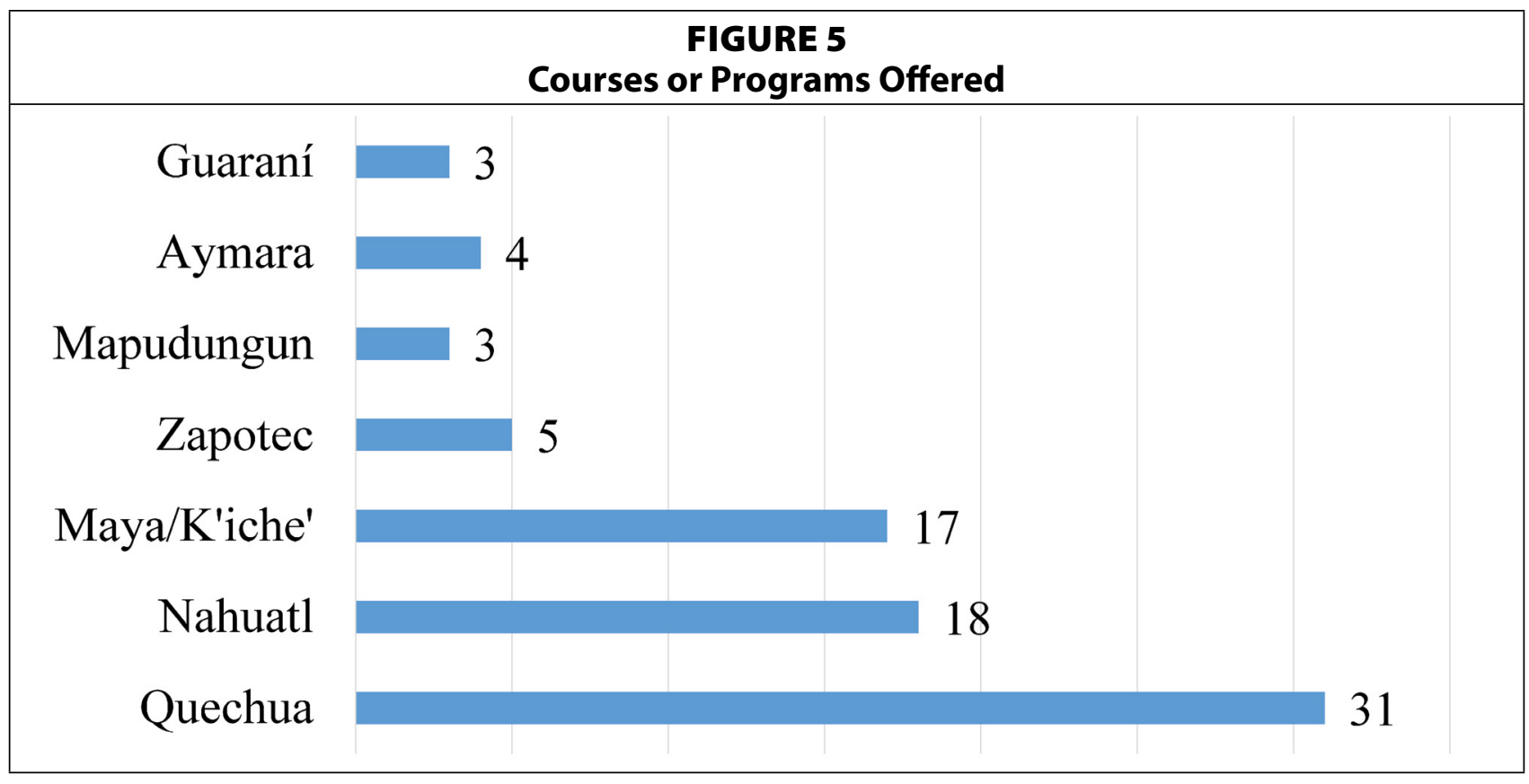

Are university libraries in the United States supporting inclusion and diversity through the purchase of Latin American Indigenous language materials?

As indicated in this study, all of the 87 university libraries considered have some representation of materials written or produced in at least one of seven Latin American Indigenous languages. However, the number of holdings in these 87 university libraries is scarce and unevenly distributed. Of all the Indigenous languages covered, Mayan languages materials have the largest number of holdings in all 87 university libraries. This data is interesting, as Quechua is the most widely spoken of the Latin American Indigenous languages. Accordingly, the universities in this study offered almost double the number of courses in Quechua language and cultures than in Mayan languages.

The rest of the materials in Nahuatl, Guaraní, Aymara, Zapotec, and Mapudungun languages have significantly smaller numbers of holdings, with Mapudungun languages materials as the least represented, with only 2.5 percent representation among holdings in all of the seven languages. This data suggests that, although these university libraries have acquired materials in these languages, the representation of these materials is still low, presenting an opportunity for growth. For librarians contemplating the creation of an inclusive collection covering any Latin American Indigenous language, this stunted representation requires collection development attention. 


\section{Courses and Programs}

Figure 1 shows that only two universities, the University of Texas at Austin and Tulane University, have more than 1,000 holdings of materials. Although these two universities have offered courses or programs (Tulane University's Department of History offers a Seminar in Historical Nahuatl ${ }^{47}$ the University of Texas at Austin's Teresa Lozano Long Center of Latin American

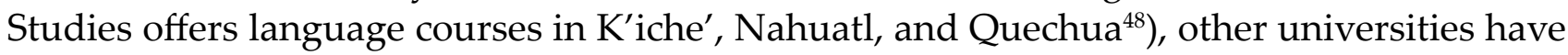
offered more or as many programs. To illustrate, UCLA has offered courses or programs in Quechua, Nahuatl, and Maya. ${ }^{49}$ Similarly, the University of California, Berkeley's Linguistic department has offered courses in Quechua, Aymara, and Mayan languages. ${ }^{50}$

Notwithstanding, there is a correlation between courses and programs offered and the number of materials held by universities. An examination of courses offered, and number of materials held, for the top five universities with the most holdings (see figure 2) and the five universities with the fewest holdings (see figure 3 ) shows that the universities with more materials had offered more courses or programs in any of these Indigenous languages than the universities with fewer materials. To illustrate, three of the universities with the smallest holding of materials - the University of Oklahoma (OKS), Auburn University in Alabama (AAA), and Case Western Reserve University (CWR) - did not have any courses or programs in any of the languages covered in this study.

There are some exceptions. Duke University is not one of the universities with most holdings but had offered a course or program in Quechua, Maya, and Aymara. ${ }^{51}$ Conversely, Princeton University is one of the universities that holds more than 500 items; yet an internet search in this university's website did not show courses offered in any of the languages covered in this study. Nonetheless, this university offered a course on Indigenous Brazil. ${ }^{52}$

Some universities have shown initiatives of inclusion and diversity by offering courses in these less commonly taught languages. These courses are offered in university campuses and through programs abroad, in which universities in the United States collaborate with institutions in Latin American countries offering opportunities to study a language and culture in a foreign country. For example, the University of Kansas's (KU) Center for Latin American \& Caribbean Studies offers annual classes in Quechua. These classes are offered at both KU's campus and abroad through language summer programs. ${ }^{53}$ Similarly, the University of Michigan's Center for Latin American \& Caribbean Studies also offers a Quechua and Nahuatl language program abroad and in house. ${ }^{54}$

Another example that shows initiatives for inclusion for these Indigenous languages involves the partnership among Columbia, Cornell, and Yale universities, which offered an e-course in elementary Nahuatl through a two-way videoconferencing platform. ${ }^{55}$ An interesting initiative that may boost a collaboration between a university library and a campus group is the creation of study groups focusing on these Indigenous languages. For example, in 2016, the Latin American and Caribbean Studies Institute and the Latin American Indigenous Languages initiative at the University of Georgia supported a Nahuatl study group, which studied this language, its literature, and culture. ${ }^{56}$

The exploration of cultures, literatures, and their languages such as Quechua, Nahuatl, $\mathrm{K}^{\prime}$ iche', Mapudungun, Zapotec, and Aymara promotes the cultural recovery of these languages and cultures and enhances students' opportunities to be global learners by appreciating cultures other than their own. For courses that target the learning of an Indigenous language, the library plays a relevant role by offering books and materials that may benefit the learning experience, regardless of whether or not a given Indigenous language fulfills a foreign language requirement. ${ }^{57}$ 


\section{Recommendations}

What initiatives could university libraries take to further the revitalization and advancement of Latin American Indigenous languages?

There are a number of initiatives that could advance Latin American Indigenous languages. The initiatives mentioned in this section consider the formulation of courses that address the bicultural nature of Indigenous authors and different approaches to Indigenous cultures, collaboration between librarians and professors, collaborative collection development, and modification of approval plans to cover book vendors that provide nonmainstream Indigenous topics.

Latin American Indigenous languages represent ancestral and continuing cultures that university libraries could help revitalize and prolong. Espino Relucé refers to the bicultural and monocultural nature of authors writing in original languages. ${ }^{58}$ Although Espino Relucé interprets monocultural as a desire for Indigenous authors to keep their work available only to those who speak the language, this feature relates more to a dual quality addressing the bilingualism of these authors and their immersion in two different cultures: the Indigenous and the Hispanic. From the point of view of university professors, Latin American Indigenous cultures offer a rich opportunity to formulate courses that unveil these cultures from a variety of perspectives and generous cultural approaches. For librarians, collaborating with professors by building a collection that supports these courses provides liaison work that is inclusive, meaningful, and in sync with current trends for inclusive collection development and university libraries' strategic plans.

University libraries in the United States that are building collections that support course curricula addressing Latin American Indigenous topics may see the benefits of collaborative collection development. It makes a difference when professors and students have an opportunity to request specific titles for these courses and cooperate with subject specialists to acquire relevant titles. As stated above, one manner for liaison librarians to identify the particular needs of professors and students involved in Indigenous languages courses is through the Suggest a Library Purchase program. Addressing this program, Ibacache states that this program connects subject specialists with "the real collection needs of patrons." 59

Subject librarians may reach out to their Latin American centers and institutes outside their Spanish departments to promote the purchase of books in Indigenous languages written by Indigenous authors or about Indigenous cultures. Similarly, librarians may encourage patrons to use their university libraries' Suggest a Library Purchase program to request titles of interest regarding Latin American Indigenous languages topics. ${ }^{60}$ Therefore, when university libraries are part of this collaborative network, they could also be part of a larger narrative: that of advancing Indigenous knowledge and providing a bridge that will help students reach awareness of cultural diversity.

In addition, subject librarians may collaborate with collection development librarians to create collections that address the purchase of Latin American Indigenous language books written by Indigenous authors. These collections may include oral tradition tales, folk tales, poems and sonnets, short stories, short novels, protest novels (novela de denuncia), anticlerical novels (novela anticlerical), and other original literary works of fiction and nonfiction that represent the repertoire of Indigenous authors. Espino Relucé infers that the novels above are an extension of the voice of Indigenous authors ${ }^{61}$ Having a collection that features Indigenous authors may validate the diversity initiative of the academic library. In Alexander's words, "the next level is to acknowledge the validity of worldviews inherent in diverse groups such as American Indians." ${ }^{62}$ 
However, the acquisition of materials authored by Indigenous authors may pose a problem for university libraries whose approval plans may not cover presses or book vendors carrying these materials. One approach would be to modify approval plans to include Latin American publishing houses and other small presses that provide nonmainstream Indigenous topics and books written by Indigenous authors. Ultimately, subject librarians could share the names of these presses and book vendors with collection development librarians as an initial step to implement collection policies that advocate for access to materials written in these Indigenous languages.

The role of these nonmainstream publishers and book vendors is relevant because they may offer access to literary works written by Indigenous authors and other materials not readily found in conventional book distributors. However, there has to be a conscientious effort to connect with publishers and book vendors in Latin America even when approval plans or contracts are not feasible. For example, librarians could request catalogs systematically and inform these publishers of the current practices involving the purchase of Indigenous materials especially if they involve Indigenous authors.

Collaboration may also include librarians who work with metadata. Ann M. Doyle, Kimberly Lawson, and Sarah Dupont, referring to an "aboriginal enhanced MARC record," infer that records that thoughtfully document Indigenous content may facilitate discoverability of these materials. ${ }^{63}$ These authors add that "indigenized metadata" creates a "knowledge record" that registers Indigenous materials, supporting the preservation of Indigenous knowledge and Indigenous traditions and scholarship. ${ }^{64}$

As the data shows, books are the type of material most prevalent representing Latin American Indigenous languages in university libraries in the United States. University libraries could also build resources in formats other than books. To illustrate, Ohio State University offers a webpage devoted to promoting some resources for the study of Quechua. These resources include links to dictionaries, audio, and videos. ${ }^{65}$ Additionally, libraries could purchase nonbook resources such as films and documentaries. There are a number of films that include Latin American Indigenous languages, such as El Caso Huayanay (1981), Yawar Mallku (1969), Huicholes (2014), Kukuli (1961), Kuntur Wachana (1977), Retablo (2017), Ukamau (1966), Icaros (2014), Cochochi (2007), La Voz Mapuche (2009), La Agonía de Arauco (1917), Mataindios (2018), Ixcanul (2015), Wiñaypacha (2017), Cuando Cierro los Ojos (2019), and El Botón de Nácar (2015), among others. These films and documentaries exhibit some of the Latin American Indigenous languages and topics related to culture, everyday life, injustice, and marginality.

A different approach to advance inclusion of Latin American Indigenous languages is to host Indigenous writers in university libraries and create digital repositories. These actions may need a budget allocation; however, university libraries may benefit through efforts to provide diversity and inclusion by inviting Indigenous writers and providing digitized access to their works. The University of Pennsylvania hosted such an event as part of its Indigenous Languages Week celebration in October 2019, where the renowned Quechua writer Pablo Landeo-Muñoz and the Quechua poet Irma Alvarez-Ccoscco met the public in an evening of reading and conversation. ${ }^{66}$

Although budget allocation is problematic, especially in COVID-19 pandemic times, there are some initiatives to advance promotion of Latin American Indigenous languages and cultures. To illustrate, librarians may create libguides addressing Indigenous knowledge or to support Indigenous-related course curriculum. Librarians could create blogs to welcome 
scholarship and open a space for conversation and create book displays or, in the case of campus closures, book widgets highlighting Latin American Indigenous materials and works by Indigenous authors. Promotion could also entail communicating with Latin American centers and cohosting film festivals with these centers. Last, collaboration with Special Collections, Archives, and Preservation could boost the creation of a collection of artifacts and other art expressions that could reinforce the promotion of Latin American Indigenous materials.

Therefore, universities may play a relevant role in promoting and advocating for the survival of Indigenous cultures and languages through inclusive programs. Mendoza-Mori, referring to Quechua programs in universities in the United States, notes that universities may provide a place to "promote" and reflect on the value of preserving Indigenous languages. ${ }^{67}$ Similarly, Indigenous studies liaison librarian Jessie Loyer, and librarians Madelaine Vanderwerff, and Meagan Bowler, referring to a university library's budget allocation to support Indigenous studies in Mount Royal University in Canada, assert that universities support indigenization by creating courses with Indigenous curriculum. ${ }^{68}$

The University of Alabama proposes an interesting approach by collaborating with the National Association of Self-Instructed Language Programs. Students in this program are part of a self-learning approach where they use print and audiovisual materials and meet with a language trainer who oversees students' progress. $^{69}$ Students carry the cost of materials needed in this course. ${ }^{70}$ Even though this type of informal learning offers a good opportunity to connect students to a Latin American Indigenous language, the cost of the course may pose limitations for students to access materials or even enroll in this program. Thus, university libraries may take a lead and allocate a budget that could support the materials needed for students enrolled in such a program.

\section{Conclusion}

There appears to be an effort to disseminate knowledge of Latin American Indigenous languages and cultures in some university libraries. In fact, the need for inclusion and diversity has fueled an attempt by these universities to invigorate knowledge of these Indigenous cultures with courses and programs targeting the cultures, food, vestment, and linguistics features, among others, of these languages. However, data suggest that university libraries could do more to advance Latin American Indigenous languages by building a collection of materials representative of these Indigenous languages and cultures. To illustrate, inclusive initiatives that promote diversity could involve building a Latin American Indigenous languages and cultures collection that considers not only fiction and informational books but also films, music recordings, and other materials. Moreover, librarians may support diversity by acquiring books and materials written and produced by Indigenous authors.

University libraries could support the collection of Latin American Indigenous materials as advocates of the preservation of Indigenous knowledge and the historical truth they represent. The collection of these materials could also support inclusive course curriculum involving Indigenous topics and thus support students taking these courses. Similarly, it is important for libraries to promote these materials to create interest in hopes of opening a conversation with students, instructors, and the surrounding Indigenous communities.

As inclusion and diversity integrates in the narrative of universities' strategic plans in the United States, university libraries could align to this plan. Librarians collaborating with professors to purchase materials that could feed literature and cultures course curricula, inviting Indigenous authors to courses and university events and facilitating student involvement, 
are some of the steps involved in initiatives that advance inclusion and diversity. Finally, as university libraries become partners in the revitalization and preservation of Latin American Indigenous languages and Indigenous knowledge, these libraries would enhance students' opportunities to become global citizens.

\section{Acknowledgments}

The author is grateful to Donna Hamilton, Copy Cataloging Manager at the University of Colorado Boulder, and Zoe Surrat-Duncanson, MLIS, OCLC Customer Support Analyst, for their support explaining how to make language searches in FirstSearch using institutions' codes and the language filter; Nicole Trujillo for her assistance explaining discovery systems; Javier Muñoz-Dias, PhD in Spanish, for his advice on Indigenous authors, sharing his knowledge on the Andean region, and sharing important bibliography; and Keegan Harris, undergraduate student at the University of Colorado Boulder, for his help with dictation and data checking.

\section{Notes}

1. Quechua is recognized as the most spoken language with 8 million speakers in Latin America: University of Pennsylvania, "Penn Language Center: Quechua," https://plc.sas.upenn.edu/quechua [accessed 15 March 2020]; Mexico has one million 800 thousands speakers of Nahuatl: Gobierno de México, "Gobierno de México Impulsa el Desarrollo del Pueblo Náhuatl y Reafirma su Reconocimiento al Municipio Indígena como un Acto de Justicia," https://www.gob.mx/inpi/articulos/gobierno-de-mexico-impulsa-el-desarrollo-del-pueblo-nahuatly-reafirma-su-reconocimiento-al-municipio-indigena-como-un-acto-de-justicia [accessed 15 March 2020]; Mapudungun is spoken by around 400,000 people in Chile and Argentina, although 1.5 million people considered themselves as Mapuche: Memoriachilena Biblioteca Nacional de Chile, "La Lengua Mapuche Mapudungun," www.memoriachilena.gob.cl/602/w3-article-3594.html [accessed 15 March 2020].

2. Statista, "Share of Indigenous or Native Language Speakers in Latin America in 2018, by Country," https:// www-statista-com.colorado.idm.oclc.org/statistics/1058273/latin-america-share-Indigenous-language-speakerscountry/ [accessed 14 March 2020].

3. Britannica Academic, "Quechua," https://academic-eb-com.colorado.idm.oclc.org/levels/collegiate/article/ Quechua/62202 [accessed 16 March 2020].

4. Encyclopedia Britannica, "Mayan Languages," https://www.britannica.com/topic/Mayan-languages [accessed 16 March 2020].

5. Britannica Academic, “Tupí-Guaraní Languages," https://academic-eb-com.colorado.idm.oclc.org/levels/ collegiate/article/Tup\%C3\%AD-Guaran\%C3\%AD-languages/73800 [accessed 16 March 2020].

6. Britannica Academic, "Aymaran Languages," https://academic-eb-com.colorado.idm.oclc.org/levels/collegiate/article/Aymaran-languages/11504 [accessed 16 March 2020].

7. Britannica Academic, "Nahuatl Language," https://academic-eb-com.colorado.idm.oclc.org/levels/collegiate/article/Nahuatl-language/54677 [accessed 16 March 2020]; Britannica Academic, "Zapotec," https:// academic-eb-com.colorado.idm.oclc.org/levels/collegiate/article/Zapotec/78258 [accessed 16 March 2020].

8. Britannica Academic, "Mapuche," https://academic-eb-com.colorado.idm.oclc.org/levels/collegiate/article/ Mapuche/50706 [accessed 16 March 2020].

9. University of Colorado Boulder, "Mission, Values and Strategic Plan," https://www.colorado.edu/libraries/ about/mission-values-and-strategic-plan [accessed 28 May 2020].

10. American Council on Education, "On the Importance of Diversity in Higher Education," (2012), https:// www.acenet.edu/Documents/BoardDiversityStatement-June2012.pdf [accessed 28 May 2020].

11. "American Library Association Strategic Directions," www.ala.org/aboutala/sites/ala.org.aboutala/files/ content/governance/StrategicPlan/Strategic\%20Directions\%202017_Update.pdf [accessed 4 December 2019].

12. Ibid.

13. One of the strategies mentioned in the American Library Association Strategic Directions states: "Build a national advocacy campaign based on existing advocacy assets which focus on the values of equity, diversity, and inclusion; empower all ALA members to advocate within their workplace, their community and beyond."

14. Gonzalo Espino Relucé, Narrativa Quechua Contemporánea: Corpus y Proceso (1974-2017), ed. J.E. Primaraón (Puente Piedra, Lima, Perú: Pakarina Ediciones, 2019), 27-28. 
15. Espino Relucé, Narrativa Quechua Contemporánea, 14-28.

16. Espino Relucé, Narrativa Quechua Contemporánea, 14-15.

17. Espino Relucé, Narrativa Quechua Contemporánea, 17-18.

18. Tamara Vidal Guerrero, "La Poética de la Transculturación: Acercamiento a la Narrativa de Macedonio Villafán," Revista Chilena de Literatura, no. 98 (Noviembre 2018): 231.

19. Guerrero, "La Poética de la Transculturación," 249.

20. Karine Vanthuyne, "Becoming Maya? The Politics and Pragmatics of 'Being Indigenous' in Postgenocide Guatemala," Political and Legal Anthropology Review 32, no. 2 (2009): 196.

21. Vivian Jiménez Estrada, "Contemporary Expressions of Mayan Indigenous Knowledge: Politics and Poetry in Ixim Ulew," Dialogo 19, no. 1 (2016): 89-103, https://doi.org/10.1353/dlg.2016.0035.

22. Jiménez Estrada, "Contemporary Expressions of Mayan Indigenous Knowledge," 90.

23. Jiménez Estrada, "Contemporary Expressions of Mayan Indigenous Knowledge," 99.

24. Seminar on the Acquisition of Latin American Library Materials, "Mission, Organization, Activities, and Documents," https://salalm.org/mission-org-activities-documents/\# [accessed 20 May 2020].

25. Seminar on the Acquisition of Latin American Library Materials, "Marginalized Peoples \& Ideas Subcommittee," https://salalm.org/committees/marginalized-peoples-ideas-subcommittee/ [accessed 20 May 2020].

26. David L. Alexander, "American Indian Studies, Multiculturalism, and the Academic Library," College $\mathcal{E}$ Research Libraries 74, no. 1 (2013): 66.

27. Américo Mendoza-Mori, "Quechua Language Programs in the United States: Cultural Hubs for Indigenous Cultures," Chiricú Journal Latinoa/o Literature, Art, and Culture 1, no. 2 (2017): 47 https://doi.org/10.2979/ chiricu.1.2.05.

28. Matthew P. Ciszek and Courtney L. Young, "Diversity Collection Assessment in Large Academic Libraries," Collection Building 29, no. 4 (2010): 158, https://doi.org/10.1108/01604951011088899.

29. Jessie Loyer, Madelaine Vanderwerff, and Meagan Bowler, "Supporting Indigenous Studies Programs through Sustainable Budget Allocation," Collection Management 42, no. 3/4 (2017): 340, https://doi.org/10.1080/01 462679.2017.1337600.

30. Daniel Canosa, "Bibliotecas e Inclusión Social Coexistir en la Diversidad," Educación y Bibliotecas 20, no. 166 (2008): 88.

31. Barbara I. Dewey, "The Imperative for Diversity: ARL's Progress and Role," portal: Libraries \& the Academy 9, no. 3 (2009): 356.

32. Daniel Canosa, "Bibliotecas Indígenas," El Orejiverde, no. 56 (2015): 3, www.elorejiverde.com/attachments/ article/56/BibliotecasIndigenas.pdf.

33. Canosa, "Bibliotecas Indígenas," 3-4.

34. Florence Dedzoe-Dzokoto Plockey, "Indigenous Knowledge Production, Digital Media and Academic Libraries in Ghana," Journal of Pan African Studies 8, no. 4 (2015): 34.

35. Dedzoe-Dzokoto Plockey, "Indigenous Knowledge Production, Digital Media and Academic Libraries in Ghana," 35.

36. Dedzoe-Dzokoto Plockey, "Indigenous Knowledge Production, Digital Media and Academic Libraries in Ghana," 40.

37. Martin Nakata, "Introduction to the Special Issue: Engaging with Indigenous Knowledge, Culture and Communities," Australian Academic \& Research Libraries 45, no. 2 (2014): 78, https://doi.org/10.1080/00048623.2014 .917785 .

38. Edgardo Civallero, "Libraries, Indigenous Peoples, Identity \& Inclusion: IFLA Libraries Serving the General Public Section," World Library and Information Congress: 73rd IFLA General Conference and Council (paper presented at the 73rd IFLA General Conference and Council, Durban, South Africa, August 19-23, 2007): 3.

39. Civallero, "Libraries, Indigenous Peoples, Identity \& Inclusion," 7.

40. Kathia Ibacache, "Forgotten Hispano-American Literature: Representation of Hispano-American Presses in Academic Libraries," College \& Research Libraries (forthcoming September 2020).

41. OCLC, "Shared Mission," https://www.oclc.org/en/home.html [accessed 25 March 2020].

42. Association of Research Libraries, "List of ARL Members," https://www.arl.org/list-of-arl-members/ [accessed 13 November 2019].

43. Yale offered a summer program in Nahuatl to undergraduates, graduates, and scholars in 1998. See "Yale Offer Program Teaching the Nahuatl Language," Yale News, accessed October 15, 2019, https://news.yale. edu/1998/02/02/yale-offer-program-teaching-nahuatl-language [accessed 15 October 2019].

44. GW Business, "Faculty Foreign Language Resources," https://business.gwu.edu/academics/programs/ international/resources/faculty-resources/language-resources [accessed 13 November 2019].

45. N.H. Hornberger and K.A. King, "Revising Quechua Language Shift in South America," in Can Threatened 
Languages be Saved? Reversing Language Shift Revisited: A 21st Century Perspective, ed. Joshua A. Fishman (New York, NY: UTP, 2000), 166.

46. Dante Gonzalez, email message to author, January 6, 2020; Mónica Aranda, email message to the author, January 3, 2020; Raúl Figueroa Sarti, email message to author, January 3, 2020.

47. Department of History, “Undergraduate Courses," accessed March 24, 2020, https://iberalarts.tulane.edu/ departments/history/academics/undergrad/courses [accessed 24 March 2020].

48. Texas Liberal Arts, "Teresa Lozano Long Center of Latin American Studies," https://liberalarts.utexas. edu/languages/latin-american-studies/ [accessed 24 March 2020].

49. UCLA Registrar's Office, “Course Descriptions," https://www.registrar.ucla.edu/Academics/CourseDescriptions [accessed 24 March 2020].

50. Berkeley Linguistics, "Graduate Field Methods Course History," https://x.berkeley.edu/graduate-fieldmethods-course-history [accessed 24 March 2020].

51. Duke Trinity College of Arts and Sciences, "Languages at Duke," https://trinity.duke.edu/languages [accessed 24 March 2020]; "Roman Studies," Duke Trinity College of Arts and Sciences, https://romancestudies. duke.edu/language-studies-kiche-maya [accessed 24 March 2020].

52. Princeton University, "Indigenous Brazil," https://commons.princeton.edu/Indigenous-brazil/ [accessed 24 March 2020].

53. KU Center for Latin American \& Caribbean Studies, “Languages of Latin America,” https:/latamst.ku.edu/ languages [accessed 15 September 2019].

54. Quechua is taught at the elementary, intermediate, and advanced level; see Center for Latin American \& Caribbean Studies, "Quechua Language Program," https://ii.umich.edu/lacs/students/language-programs/ quechua.html [accessed 15 November 2019].

55. Dorie Baker, “Three Ivies Team up for Long-Distance Teaching of Rare Languages," Yale News (December 4, 2012), https://news.yale.edu/2012/12/04/three-ivies-team-long-distance-teaching-rare-languages.

56. Department of Romance Languages, "Nahuatl Study Group," https://www.rom.uga.edu/events/content/2015/nahuatl-study-group [accessed 13 September 2019].

57. In the case of Duke University, Quechua does not fulfill its foreign language requirement, but K'iche' Maya does; see Duke Trinity College of Arts \& Sciences, “Languages at Duke," https://trinity.duke.edu/languages [accessed 13 September 2019].

58. Espino Relucé, Narrativa Quechua Contemporánea, 38.

59. Kathia Ibacache, "Building Collections through Purchase Suggestions in Academic Libraries," Collection Management (2019): 1-14, https://doi.org/10.1080/01462679.2019.1666332.

60. The Suggest a Library Purchase, used as a collection development tool, may help subject specialist to identify Indigenous languages authors and Indigenous languages subject trends. See Kathia Ibacache, "The Suggest a Library Purchase Program at the University of Colorado Boulder," Collection Management (2019): 1-9, https://doi.org/ 10.1080/01462679.2019.1650153.

61. Espino Relucé, Narrativa Quechua Contemporánea, 31.

62. Alexander, "American Indian Studies, Multiculturalism, and the Academic Library," 67.

63. Ann M. Doyle, Kimberly Lawson, and Sarah Dupon, "Indigenization of Knowledge Organization at the Xwi7xwa Library," Journal of Library and Information Studies 13, no. 2 (2015): 120, https://doi.org/10.6182/ jlis.2015.13(2).107.

64. Doyle, Lawson, and Dupon, "Indigenization of Knowledge Organization at the Xwi7xwa Library," 125.

65. Center for Latin American Studies, "Resources for the Study of Quechua," https://clas.osu.edu/resources/ quechua [accessed 15 October 2019].

66. Quechua at Penn, “Quechua Writers Pablo Landeo-Muñoz \& Irma Álvarez-Ccoscco,” http://web.sas.upenn. edu/quechua/2019/10/16/pablo-landeo-irma-alvarez-ccoscco/ [accessed 15 November 2019].

67. Américo Mendoza-Mori, "Quechua Language Programs in the United States: Cultural Hubs for Indigenous Cultures," Chiricú Journal Latinoa/o Literature, Art, and Culture 1, no. 2 (2017): 46, https://doi.org/10.2979/ chiricu.1.2.05.

68. Loyer, Vanderwerff, and Bowler, "Supporting Indigenous Studies Programs through Sustainable Budget Allocation," 338.

69. Department of Modern Languages and Classics, "2019-20 Undergraduate Catalog," https://catalog.ua.edu/ undergraduate/arts-sciences/modern-languages-classics/ [accessed 5 October 2019].

70. Telephone conversation with a staff member from the Department of Modern Languages and Classics from the University of Alabama, October 2019. 